\title{
PELAKSANAAN ATAU EKSEKUSI PUTUSAN BADAN ARBITRASE SYARIAH NASIONAL (BASYARNAS) SEBAGAI KEWENANGAN PENGADILAN AGAMA
}

\author{
Ummi Uzma ${ }^{1}$
}

\begin{abstract}
The authority of the implementation or execution of the decision of the Arbitration Board of the National Sharia laws still the Law No. 30 Year 1999 on Arbitration and Dispute Resolution Options Article 61, which is the authority of the District Court. This is not in accordance with what the task of the National Islamic Arbitration Board has the task of resolving disputes in the field of Islamic economics Arbitration. Economic matters according to Sharia Law No. 3 of 2006 on the Amendment of Act No. 7 of 1989 on religious court expressly states that under Article 49 of Islamic Economics is the absolute authority of religious courts. Therefore, there are two opinions on this matter. First, the authority is the authority of the District Court, so the ruling National Islamic Arbitration Board under the authority of the District Court. Secondly, argues that all related to Islamic economic settlement under Article 49 point (i) within its jurisdiction, this opinion is based on the legal principle of lex posteriori derogat legi priori and lex specialis legi generali derogat. In addition, Article 1 (3) of the 1945 Constitution, the Republic of Indonesia is a state law in which there are two terms, namely the supreme of law and equality before the law. Interpretation of the supreme law of the rule of law. Article 61 of Law No. 301999 is a legal certainty for the parties to the dispute in the arbitration field. Regarding the notion of equality before the law which is the same position before the law, so the position of district courts and religious courts are equal before the parties dispute arbitration, but because of the religious courts have been justified by the law that the court has absolute authority on the religion of Islamic economics is a dispute case -sengketa at the National Islamic Arbitration everything in the field of Islamic economics it is appropriate if the implementation or execution of the decision of the National Islamic Arbitration Court at the turn to religion.
\end{abstract}

Keywords: sharia, arbitration, court, district court

\begin{abstract}
Abstrak
Kewenangan pelaksanaan atau eksekusi putusan Badan Arbitrase Syariah Nasional secara peraturan perundang-undangan masih memakai UndangUndang Nomor 30 Tahun 1999 tentang Arbitrase dan Pilihan Penyelesaian Sengketa Pasal 61 yang merupakan kewenangan Pengadilan Negeri. Hal ini

\footnotetext{
1 Penulis adalah Mahasiswa Program Doktor Ilmu Hukum Universitas Sriwijaya Palembang. Alamat kontak: sundari165@gmail.com.
} 
tidak sesuai dengan apa yang menjadi tugas dari Badan Arbitrase Syariah Nasional yang mempunyai tugas menyelesaikan sengketa-sengketa Arbitrase di bidang ekonomi syariah. Perkara-perkara Ekonomi Syariah menurut UndangUndang Nomor 3 Tahun 2006 tentang Perubahan Atas Undang-Undang Nomor 7 Tahun 1989 tentang Peradilan Agama secara tegas bahwa dalam Pasal 49 menyebutkan kewenangan penyelesaian sengketa Ekonomi Syariah merupakan kewenangan absolut dari Pengadilan Agama. Oleh karenanya ada dua pendapat mengenai hal ini. Pertama, kewenangan eksekusi putusan Badan Arbitrase Syariah Nasional tersebut merupakan wewenang Pengadilan Negeri. Kedua, berpendapat bahwa semua yang berkaitan dengan penyelesaian sengketa ekonomi syariah berdasarkan Pasal 49 huruf (i) merupakan kewenangan Pengadilan Agama, pendapat ini didasarkan kepada asas hukum lex posteriori derogat legi priori dan lex specialis derogat legi generali. Selain itu Pasal 1 ayat (3) UUD 1945, Negara Republik Indonesia adalah negara hukum yang di dalamnya ada dua pengertian yaitu supreme of law dan equality before the law. Penafsiran terhadap supreme of law yaitu kepastian hukum. Pasal 61 UU No. 301999 merupakan suatu kepastian hukumnya untuk para pihak yang bersengketa di bidang Arbitrase. Mengenai pengertian equality before the law yaitu sama kedudukan di depan hukum, jadi kedudukan pengadilan negeri dan pengadilan agama sama di depan para pihak sengketa arbitrase, tetapi karena pengadilan agama telah dijustifikasi oleh undangundang bahwa pengadilan agama mempunyai kewenangan absolut terhadap penyelesaian sengketa ekonomi syariah, dan sengketa-sengketa ekonomi syariah dapat pula diselesaikan melalui jalur nonlitigasi di Badan Arbitrase Syariah Nasional semuanya di bidang ekonomi syariah, maka tepatlah apabila pelaksanaan atau eksekusi putusan Badan Arbitrase Syariah Nasional di alihkan ke Pengadilan Agama

\section{Pendahuluan}

Pada tanggal 20 Maret 2006 Presiden Republik Indonesia telah mengesahkan Undang-Undang Nomor 3 Tahun 2006 tentang Perubahan Atas Undang-Undang Nomor 7 Tahun 1989 tentang Peradilan Agama.

Perubahan dalam UU No. 3 Tahun 2006 yang sangat fenomenal dalam sejarah Pengadilan Agama kewenangan baru yang merupakan perluasan kewenangan Pengadilan Agama untuk memeriksa, memutus, dan menyelesaikan perkara di tingkat pertama antara orang-orang yang beragama Islam di bidang syariah.

Dalam penjelasan Pasal I angka 37 mengenai Perubahan Bunyi Pasal 49 UU No. 7 Tahun 1989, pada poin (i) disebutkan bahwa yang dimaksud dengan 
ekonomi syariah adalah perbuatan atau kegiatan usaha yang dilaksanakan menurut prinsip syariah meliputi: ${ }^{2}$

1. bank syariah;

2. asuransi syariah;

3. reasuransi syariah;

4. reksadana syariah;

5. obligasi syariah dan surat berharga berjangka menengah syariah;

6. sekuritas syariah;

7. pembiayaan syariah;

8. pegadaian syariah;

9. dana pensiun lembaga keuangan syariah;

10. bisnis syariah; dan

11. lembaga keuangan mikro syariah.

Arbitrase adalah cara penyelesaian suatu sengketa perdata di luar peradilan umum, yang didasarkan pada perjanjian arbitrase yang dibuat secara tertulis oleh para pihak yang bersengketa Pasal 1 angka 1 UU No. 30 Tahun 1999 tentang Arbitrase Dan Alternatif Penyelesaian Sengketa (selanjutnya disebut UU No. 30 Tahun 1999). ${ }^{3}$

Sengketa dengan cara penyelesaiannya melalui arbitrase itu didasarkan atas kesepakatan yang dibuat atas dasar perjanjian tertulis dari para pihak, tidak semua sengketa dapat diselesaikan melalui arbitrase, melainkan hanya sengketa mengenai hak yang menurut hukum (Perjanjian tertulis para pihak).

Pasal 5 UU No. 30 Tahun 1999 mengatur tentang kompetensi absolut atau objek sengketa yang dapat diselesaikan melalui arbitrase hanya sengketa di bidang perdagangan dan mengenai hak yang menurut hukum dan peraturan perundang-undangan dikuasai sepenuhnya oleh pihak yang bersengketa. ${ }^{4}$

Mengenai prosedur berperkara di BASYARNAS telah diatur dengan sistematis sejak masih didirikan BAMUI. Secara garis besar aturan tersebut dituangkan dalam peraturan prosedur Badan Arbitrase Muamalat Indonesia (BAMUI) yang diberlakukan sejak 21 Oktober 1993. Beberapa tambahan yang terjadi setelah hanya bersifat teknis untuk menyempurnakan aturan yang telah ditetapkan sebelumnya. Sepanjang aturan tersebut tidak bertentangan dengan Undang-Undang No. 30 tahun 1999. Adapun prosedur penyelesaian sengketa melalui BASYARNAS dimulai dengan penyerahan secara tertulis oleh para pihak yang sepakat untuk menyesaikan persengketaan melalui BASYARNAS sesuai dengan peraturan prosedur yang berlaku. Pihak yang bersengketa

${ }^{2} \mathrm{Hj}$. Sulaikin Lubis, Hj. Wismar'ain Marzuki, dan Gemala Dwi, "Hukum Acara Perdata Peradilan Agama Di Indonesia”, (Jakarta: Badan Penerbit FHUI, 2006), hal. 3.

3 Indonesia, Pasal 1 Angka 1 Undang-Undang Tentang Arbitrase Dan Alternatif Penyelesaian Sengketa, UU No. 30 Tahun 1999 tentang Arbitrase Dan Alternatif Penyelesaian Sengketa, LN No. 138

4 Syamsudin Manan Sinaga, Arbitrase Dan Kepailitan Dalam Sistem Ekonomi Syariah, "Majalah Hukum Nasional”, No.12 Tahun 2007 BPHN, hal. 172. 
sepakat akan menyelesaikan persengketaan mereka dengan ishlah (perdamaian) tanpa ada suatu persengketaan berkenaan dengan perjanjian atas pemintaan para pihak tersebut. Kesepakatan ini dicantumkan dalam klausula arbitrase.

\section{Pembahasan}

Arbitrase atau arbitrage (Belanda), arbitrase (Latin), Tahkim (Islam) ialah istilah-istilah yang dipakai menurut bahasa. Para pakar ahli hukum dan peraturan perundang-undangan memberikan pengertian-pengertian mengenai Arbitrase sebagai berikut: ${ }^{5}$

1. Prof. R. Soebekti, arbitrase adalah suatu penyelesaian sengketa yang dilakukan oleh seorang atau beberapa orang arbiter atas dasar kebijaksanaannya dan para pihak akan tunduk pada atau mentaati putusan yang diberikan oleh arbiter yang mereka tunjuk (R. Soebekti, 1992:1)

2. Sudargo Gautama, arbitrase adalah suatu cara penyelesaian sengketa yang jauh dianggap lebih baik dari pada penyelesaian melalui saluransaluran biasa (Sudargo Gautama, 1979: 1)

3. Abdulkadir Muhammad, arbitrase adalah peradilan swasta di luar lingkungan peradilan umum yang dikenal khusus dalam dunia perusahaan. Arbitrase merupakan peradilan yang dipilih dan ditentukan sendiri secara sukarela oleh pihak-pihak yang bersengketa (Abdulkadir Muhammad dalam A. A Rahmad Rosyadi dan Ngatino, 2002:68)

4. UU No. 30 Tahun 1999 tentang Arbitrase Pasal 1ayat (1) arbitrase adalah cara penyelesaian suatu sengketa perdata di luar peradilan umum yang didasarkan pada perjanjian arbitrase yang dibuat secara tertulis oleh para pihak yang bersengketa.

Dalam lingkungan Syari'ah Islam, yang sepadan dengan arbitrase ini adalah sistem tahkim dan kata kerjanya hakkama yang bermakna menjadikan seseorang sebagai penengah/hakam bagi suatu sengketa. ${ }^{6}$

1. Sayid Sabiq menerangkan bahwa tahkim adalah suatu akad/perjanjian untuk mengakhiri pertengkaran antara dua orang yang bersengketa (Sayid Sabiq dalam A. Rachmad Rosyadi dan Ngatino, 2002: 43)

2. Abdul'Ainain Abd. Fatah Muhammad, mengatakan bahwa tahkim itu bersandarnya dua orang yang bertikai kepada seseorang yang mereka ridhoi keputusannya untuk menyelesaikan pertikaian mereka (Satria Effendi di Arbitrase Islam Di Indonesia, 1994 : 8)

Dasar hukum Arbitrase Syariah adalah adanya anjuran dari al-Quran tentang perlunya "perdamaian".

${ }^{5}$ H. Achmad Djauhari, Peran Arbitrase Dalam Sistem Ekonomi Syariah, "Majalah Hukum Nasional", No. 2 Tahun 2007 BPHN, hal. 186-187.

${ }^{6}$ Ibid., hal. 187. 
Al-Quran surat an-Nisa ayat 35 artinya:

Dan jika kamu khawatir akan ada persengketaan antara keduanya (suami isteri), maka kirimlah seorang hakam dari keluarga perempuan. Jika kedua orang hakam itu bermaksud mengadakan perbaikan (perdamaian) niscaya Allah akan memberi taufik kepada suami isteri itu. Sesungguhnya Allah maha mengetahui lagi maha pengenal.

Selain itu juga terdapat ayat-ayat di dalam Al-Quran yang menekankan perlunya "perdamaian" dalam segala hal. Ayat-ayat itu adalah: artinya:

Dalam hal peperangan terdapat dalam Al-Quran surat al-Hujarat ayat 9

Dan jika ada dua golongan dan orang-orang yang mukmin berperang maka damaikanlah antara keduanya jika salah satu dari kedua golongan itu berbuat aniaya terhadap golongan yang lain maka perangilah golongan yang berbuat aniaya itu sehingga golongan kembali kepada perintah Allah jika golongan itu telah kembali kepada perintah Allah, maka damaikanlah antara keduanya dengan adil dan berlaku adillah sesungguhnya Allah menyukai ornag-orang yang berlaku adil.

Dalam urusan rumah tangga, terdapat dalam surat an-Nisa ayat 128 artinya:

Dan jika seorang wanita khawatir akan nursyuz atau sikap tidak adil dari suaminya, maka tidak mengapa bagi keduanya mengadakan perdamaian yang sebenar-benarnya. Dan Perdamaian manusia itu menurut tabi'at kikir. Dan jika kamu menggauli dirimu dan nusjuz dan sikap tak acuh, maka sesungguhnya Allah adalah maha mengetahui apa yang kamu kerjakan.

Al-Quran surat an-Nisa ayat 114 artinya:

Tidak ada kebaikan pada kebanyakan bisikan-bisikan mereka kecuali bisikan-bisikan dari orang yang menyuruh manusia memberi sedekah atau berbuat makruf atau mengadakan perdamaian antara manusia. Dan barangsiapa yang berbuat demikian karena mencari keridhaan Allah, maka kelak kami memberi kepada pahala yang besar.

Dasar hukum Aribitrase Syariah selanjutnya adalah al-Hadits Riwayat Annasa'i yang menceritakan bahwa sesungguhnya Rasulullah berkata kepada 
Abu Syureih yang sering dipanggil Abu Hasan "Sesungguhnya Hakam itu adalah Allah dan kepada-NYA lah dimintakan keputusan hukum. Mengapa kamu dipanggil Abu al-Hakam? Jawab Abu Syureih "Bahwa sesungguhnya kaumku jika bertentangan akan datang kepadaku minta penyelesaian dan kedua belah pihak akan rela dengan putusanku”. Rasullah berkomentar "Alangkah baiknya perbuatanmu itu hai Abu Syureih. Apakah kamu mempunyai anak? "Jawab Abu Syureih" ya saya mempunyai anak bernama Syureih, Abdu dan Musallam. "Siapa yang paling tua?" tanya Rasul, jawab Abu Syureih" yang paling tua adalah Syureih Rasulullah, "kalau begitu engkau adalah Abu Syureih"

Selain al-Quran dan al-Hadis juga Ijma' (kesepakatan) ulama-ulama dari kalangan sahabat Rasulullah atas keabsahan praktek tahlim. Pada masa sahabat telah terjadi segketa secara arbitrase di kalangan para sahabat dan tak seornag pun yang menentangnya.

Adapun beberapa pendapat dari pakar ahli hukum tentang pentingnya keberadaan Arbitrase Syariah, sebagai berikut:

1. Sayyid Sabiq, ${ }^{7}$ bahwa penghormatan terhadap perjanjian menurut Islam hukumnya wajib, melihat pengaruhnya yang positif dan perannya yang sangat besar dalam memelihara perdamaian dan melihat urgensinya dalam mengatasi kemuskilan, menyelesaikan perselisihan dan menciptakan kerukunan.

2. H. Hartono Mardjono, ${ }^{8}$ nahwa adanya "lembaga permanen" yang berfungsi untuk menyelesaikan kemungkinan terjadinya sengketa perdata diantara bank-bank syariat dengan para nasabahnya, atau khususnya menggunakan jasa mereka, dan umumnya antara sesama umat Islam yanga melakukan hubungan-hubungan keperdataan yang menjadinya syariat sebagai dasarnya adalah kebutuhan yang sungguhsungguh nyata.

3. Rachmadi Usman, ${ }^{9}$ bahwa kelahiran badan arbitrase berdasarkan syariat Islam tersebut disambut hangat oleh berbagai pihak, bukan saja disebabkan oleh maraknya kesadaran dan keinginan umat terhadap pelaksanaan hukum Islam, melainkan juga didorong oleh suatu kebutuhan riil adanya praktik peradilan perdata secara perdamaian selaras dengan perkembangan ekonomi keuangan dikalangan umat Islam.

4. H. Pranowo Gandasubrata, ${ }^{10}$ bahwa undang-undang itu terkadang terasa kejam atau kaku, karena undang-undang itu untuk kepastian hukum

${ }^{7}$ Sayyid Sabiq, “Fikih Sunnah 11”, (Bandung: PT. Alma'Arif, 1980), hal. 173.

${ }^{8}$ H. Hartono Mardjono, "Menegakan Syariat Islam Dalam Konteks Ke Indonesiaan”, (Bandung: Mizan, 1981), hal.66.

9 Rachamadi Usman, "Hukum Ekonomi Dalam Dinamika", (Jakarta: Djambatan, 2000), hal. 100 . 
harus diterapkan, tetapi melalui arbitrase, sisi kejam dari suatu penerapan hukum dapat diatasi dengan penerapan musyarwarah dan mufakat bernafaskan Islam. Untuk itulah diharapkan Badan Arbitrase Muamalat Indonesia (BAMUI) akan subur berkembang apabila benarbenar para arbiter dalam membuat putusan benar-benar mengaryakan sesuatu yang sebaik-baiknya, sehingga kpercayaan umat semakin bertambah dan Badan Arbitrase Muamalat Indonesia (BAMUI) akan berkembang dan memenuhi harapan masyarakat.

5. H.M. Thahir Azhari, ${ }^{11}$ bahwa kehadiran Arbitrase Islam di Indonesia merupakan suatu conditio sine qua non.

Prosedur arbitrase dimulai dengan didaftarkannya surat permohonan para pihak yang bersengketa oleh sekretaris BASYARNAS. Berkas permohonan tersebut mesti mencantumkan alamat kantor atau tempat tinggal terakhir atau kantor dagang yang dinyatakan dengan tegas dalam klausula arbitrase. Berkas permohonan itu berisikan nama lengkap, tempat tinggal atau tempat kedudukan kedua belah pihak atau para pihak. Berkas juga memuat uraian singkat tentang duduknya sengketa dan juga apa yang dituntut. Pada dasarnya pengadilan negeri tidak berwenang untuk mengadili sengketa para pihak yang telah terikat dalam perjanjian arbitrase. ${ }^{12}$

Pemeriksaan atas sengketa arbitrase harus diselesaikan dalam waktu paling lama 180 hari sejak arbiter atau majelis arbitrase terbentuk. Jika diperlukan, maka jangka waktu ini dapat diperpanjang. Mengenai biaya pemanggilan dan perjalanan saksi atau saksi ahli dibebankan kepada pihak yang meminta. Apabila pemeriksaan sengketa telah selesai, pemeriksaan segera ditutup dan ditetapkan hari sidang untuk mengucapkan putusan arbitrase. Putusan diucapkan dalam waktu paling lama 30 hari setelah pemeriksaan ditutup. Selanjutnya dalam waktu 14 hari setelah putusan diterima, para pihak dapat mengajukan kepada arbiter atau majelis arbitrase untuk melakukan koreksi terhadap kekeliruan administratif dan atau menambah atau mengurangi sesuatu tuntutan putusan.

Kesepakatan penyelesaian sengketa atau beda pendapat secara tertulis adalah final dan mengikat para pihak untuk dilaksanakan dengan itikad baik serta wajib didaftarkan di Pengadilan Negeri dalam waktu paling lama 30 (tiga puluh) hari sejak pendaftaran.

10 Badan Arbitrase Muamalat Indonesia (BAMUI), Sambutan Ketua Mahkamah Agung Republik Indonesia Pada Peresmian Badan Arbitrase Muamalat Indonesia, Badan Arbitrase Muamalat Indonesia (BAMUI), Jakarta, 1994, hal. 10.

11 H.M. Thahir Azhari, Islam, Hukum Islam Dan Eksistensi Arbitrase Islam DI Indonesia, Dalam Arbitrase Islam di Indonesia, Badan Arbitrase Muamalat Indonesia (BAMUI), Bank Muamalat Indonesia (BMI), Jakarta, 1994, hal. 12.

12 Warkum Sumitro, “Asas-Asas Perbankan Islam dan Lembaga-Lembaga Terkait (BAMUI \& TAKAFUL) di Indonesia”, (Jakarta: PT. Raja Grafindo Persada, 1997), hal. 149. 
Terhadap keputusan arbitrase, para pihak dapat mengajukan permohonan pembatalan apabila putusan tersebut diduga mengandung unsur-unsur sebagai berikut:

1. surat dokumen yang diajukan dalam pemeriksaan setelah putusan dijatuhkan, diakui palsu atau dinyatakan palsu;

2. setelah putusan diambil ditemukan dokumen yang bersifat menentukan, yang disembunyikan oleh pihak lawan; atau

3. putusan diambil dari hasil tipu muslihat yang diakui oleh salah satu pihak dalam pemeriksaan sengketa.

Permohonan pembatalan tersebut harus diajukan secara tertulis ditujukan kepada Ketua Pengadilan Negeri, dalam waktu paling lama 30 hari terhitung sejak hari penyerahan dan pendaftaran putusan arbitrase kepada Panitera Pengadilan Negeri. Jika permohonan pembatalan tersebut dikabulkan, maka Ketua Pengadilan Negeri dalam waktu paling lama 30 hari sejak permohonan pembatalan diajukan, menjatuhkan putusan pembatalan.

Dalam hal ini, para pihak dapat mengajukan permohonan banding ke Mahkamah Agung yang memutuskan dalam tingkat pertama dan terakhir. Mahkamah Agung juga hanya diberi waktu maksimal 30 hari untuk memutuskan permohonan banding tersebut.

Di dalam UU No. 30 Tahun 1999, aturan hukum mengenai Pendaftaran Putusan dan Pelaksanaan atau Eksekusi putusan arbitrase, hanya memuat kewenangan Pengadilan Negeri, tidak memuat kewenangan Pengadilan Agama, oleh karenanya ada dua pendapat mengenai hal ini. Pertama, kewenangan tersebut merupakan wewenang Pengadilan Negeri, berdasar Pasal 59, Pasal 61, Pasal 62, Pasal 63 dan Pasal 64 UU No. 30 Tahun 1999, sehingga putusan Badan Arbitrase Syariah Nasional menjadi kewenangan Pengadilan Negeri. Kedua, berpendapat bahwa semua yang berkaitan dengan penyelesaian ekonomi syariah berdasar Pasal 49 huruf (i) merupakan kewenangan Pengadilan Agama, pendapat ini didasarkan kepada asas hukum lex posteriori derogat legi priori dan lex specialis derogat legi generali.

Berdasarkan asas lex posteriori derogat legi priori, peraturan perundang-undangan yang lebih baru didahulukan berlakunya daripada peraturan perundang-undangan yang lebih lama/terdahulu. Sedangkan menurut asas lex specialis derogat legi generali, yaitu peraturan perundang-undangan yang sifatnya khusus didahulukan berlakunya daripada peraturan perundangundangan yang sifatnya umum.

Kewenangan Pengadilan Agama untuk melaksanakan Putusan atau Eksekusi Basyarnas sangatlah tepat sesuai dengan asas hukum lex posteriori derogat legi priori dan lex specialis derogat legi generali. Untuk itu, dasar kewenangan perluasan kewenangan Peradilan Agama adalah sesuai dengan kebutuhan masyarakat.

Berdasarkan kedua asas hukum tersebut, dimana Undang-Undang Nomor 3 Tahun 2006 tentang Peradilan Agama sebagai perubahan atas undang-undang Peradilan Agama yang lama, yang diundangkan pada tanggal 20 Maret 2006, merupakan undang-undang terbaru dibanding undang-undang Arbitrase yang diundangkan pada tanggal 12 Agustus 1999. Begitu pula, 
undang-undang Peradilan Agama merupakan undang-undang bersifat khusus dalam penyelesaian ekonomi syariah, yang sebelumnya merupakan bagian dari kewenangan Pengadilan Negeri/Pengadilan Niaga yang berada dalam lingkup Peradilan Umum.

Dalam kasus antara PT. Atriumastra Sakti melawan PT. Bank Syariah Mandiri telah diselesaikan oleh Badan Arbitrase Syariah Nasional pada tanggal 16 Spetember 2009 Nomor 16/Th 2008/Basyarnas.

Terhadap putusan Badan Arbitrase Syariah Nasional telah dimohonkan pembatalannya ke Pengadilan Agama Jakarta Pusat oleh PT. Bank Syariah Mandiri pada tanggal 10 November 2009 dengan dasar ketentuan Pasal 70 dan Penjelasan Umum Bab VII Undang-Undang Nomor 30 Tahun 1999. UndangUndang Nomor 3 Tahun 2009 tentang Pengadilan Agama, SEMA Nomor 8 Tahun 2008 Tentang Eksekusi Badan Arbitase Syariah (sekarang telah dicabut dan tidak berlaku lagi).

Dalam perkara permohonan putusan Badan Arbitrase Syariah Nasional tersebut tercatat dalam perkara Nomor 792/Pdt.G/2009/PA.JP. Atas putusan Pengadilan Agama Jakarta Pusat yang membatalkan putusan Badan Arbitrase Syariah Nasional tersebut, PT. Atriumastra Sakti dan Arbiter Badan Arbitrase Syariah Nasional mengajukan permohonan banding Ke Mahkamah Agung dengan Termohon Banding adalah PT. Bank Syariah Mandiri.

Atas putusan Mahkamah Agung tersebut, PT. Bank Syariah Mandiri mengajukan permohonan peninjauan kembali dalam putusan Nomor 56 PK/AG/2011 tanggal 1 Desember 2011 Mahkamah Agung telah menolak permohonan Peninjauan Kembali dari Penohon Peninjauan Kembali PT. Bank Syariah Mandiri.

Pertimbangan Mahkamah Agung dalam tingkat banding tersebut diantaranya adalah putusan Pengadilan Agama telah melampui kompetensinya karena Pasal 71 Undang-Undang Nomor 1999 berbunyi sebagai berikut: Permohonan Pembatalan Administrasi harus diajukan kepada Panitera Pengadilan Negeri, sedangkan kewenangan Pengadilan Agama menurut Pasal 49 Uundang-Undang Nomor 3 Tahun 2006 adalah kewenangan tentang sengketa Perbankan Syariah.

Pendapat Mohammad Daud Ali mengenai pengertian asas hukum, yaitu kebenaran yang digunakan sebagai tumpuhan berpikir dan alasan pendapat terutama dalam penegakan dan pelaksanaan hukum. ${ }^{13}$ Asas hukum umum Islam menurutnya, yaitu asas keadilan, asas pertanggungjawaban, hukum dan asas kemanfaatan. ${ }^{14}$ Arbitrase Syariah berlandaskan pada pondasi dasar mengusung keadilan dalam penyelesaian sengketa para pihak, pertanggung

${ }^{13}$ Mohammad Daud Ali, "Hukum Islam: Pengantar Ilmu Hukum dan Tata Hukum Islam Di Indonesia”, (Jakarta: PT. Raja Grafindo Persada, 2000), hal. 114.

${ }^{14}$ Prinsip dan Asas memiliki arti yang sama. Asas berasal dari bahasa arab, yaitu asasun yang berarti dasar, basis dan pondasi. Lihat Depatemen Pendidikan Nasional, Kamus Besar Bahasa Indonesia, Edisi ke-3 BalaPustaka, Jakarta, 2002, hal. 70. Prinsip, yaitu dasar atau kebenaran yang menjadi pokok dasar berfikir, bertindak dan sebagainya. Lihat Mohammad Daud Ali Ibid, hal. 896. 
jawaban hukum dari putusan Arbitrase serta kemanfaatan dari putusan arbitrase tersebut bagi para pihak yang bersengketa.

Menurut Gemala Dewi ada asas utama mendasari setiap perbuatan manusia termasuk perbuatan muamalat, yaitu asas illahiyah, asas kebebasan (al-hurriyah), asas persamaan dan kesetaraan (al-musawah), asas keadilan (al'adalah), asas kerelaan (al-ridha), asas kejujuran (ash-shidiq) dan asas tertulis (al-kitabah). ${ }^{15}$ Faturrahman Djamil mengemukakan 6 asas Hukum Perikatan Islam, yaitu asas kebebasan, asas persamaan atau kesetaraan, asas keadilan, asas kerelaan, asas kejujuran, asas kebenaran dan asas tertulis. ${ }^{16}$

Asas-asas hukum Islam tersebut dipakai untuk rekontruksi Badan Arbitrase Syariah Nasional baik sudut kelembagaan, eksetensi dan aturan hukumnya terutama mengenai kewenangan eksekusi dan pembatalan putusannya.

Asas hukum perdata Indonesia digunakan pula sebagai pondasi dan dasar dalam menetapkan kontruksi Badan Arbitrase Syariah Nasional, yaitu asas kebebasan berkontrak (asas constracts vrij heid atau party autonomis). Mengandung pengertian bahwa, setiap orang dapat mengadakan perjanjian apapun juga, baik yang telah diatur dalam undang-undang maupun yang belum diatur dalam undang-undang. ${ }^{17}$ Asas kebebasan berkontrak memberikan kebebasan kepada para pihak untuk:

1. membuat atau tidak membuat perjanjian;

2. mengadakan perjanjian dengan siapapun;

3. menentukan isi perjanjian, pelaksanaan, dan persyaratan;

4. menentukan bentuk perjanjiannya apakah tertulis atau lisan.

Asas-asas hukum perikatan lain dapat digunakan, adalah:

1. Undang-undang bagi mereka yang membuatnya (pacta sunt servanda, atau setiap janji adalah mengikat).

2. Asas kebebasan dalam membuat perjanjian atau persetujuan (asas contracts virh held atau party autonomis).

3. Asas bahwa persetujuan harus dilaksanakan dengan i'tikad baik (asas T.e. geode trouw).

Islam, sekurang-kurangnya menurut keyakinan para pemeluknya (ummatan muslimatan), ${ }^{18}$ adalah agama yang tidak hanya mengatur persoalan

${ }^{15}$ Gemala Dewi, et.al., "Hukum Perikatan Islam Di Indonesia”, (Jakarta: Kencana, 2013), hal. 30-38.

16 Faturrahman Djamil, "Hukum Perjanjian Syariah", Dalam Mariam Darus Badarulzaman, et.al., "Kompilasi Hukum Perdata", (Bandung: Citra Aditya Bukti, 2001), hal. 249-251.

17 Pasal 1338 ayat (1) Kitab Undang-Undang Hukum Perdata, menyatakan bahwa semua perjanjian yang dibuat secara sah berlaku sebagai undang-undang bagi mereka yang membuatnya. 
akidah dan ibadah; akan tetapi, juga memberikan landasan utama tentang norma-norma dasar etika bermuamalah. Termasuk untuk tidak menyatakan terutama dalam hal-hal yang berkaitan erat dengan persoalan-persoalan ekonomi dan keuangan syariah seperti perdagangan/niaga (tijarah, traffic), sewa-menyewa (ijaraj, leasing), gadai (rahn; pladge), utang-piutang (mudayanah, debit and credit), upah-mengupah (ujrah; fee) dan lain-lain khususnya.

Berbagai aktivitas bisnis syariah berpotensi menimbukan sengketa. Meskipun sengketa sesungguhnya tidak dikehendaki dalam hubungan bisnis, namun para pihak sebagai pelaku bisnis selalu mencantumkan mekanisme penyelesaian dalam perjanjian atau akad yang mereka perbuat. Pencantuman mekanisme penyelesaian sengketa ini lebih bersifat antisipasi atas kemungkinan terjadinya sengketa dalam hubungan bisnis yang terjadi.

Perjanjian arbitrase bukan perjanjian "bersyarat" atau "voorwaardelijke verbentenis". Oleh karena itu, pelaksanaan perjanjian arbitrase tidak bergantung pada suatu kejadian tertentu di masa yang akan datang. Perjanjian arbitrase tidak mempersoalkan masalah pelaksanaan perjanjian, tetapi hanya mempersoalkan masalah cara dan lembaga berwenang menyelesaikan perselisihan yang terjadi antara pihak yang berjanji. ${ }^{19}$

Perjanjian arbitrase mencantumkan atau menyepakati suatu cara penyelesaian sengketa yang timbul di masa yang akan datang. Selanjutnya syarat yang terdapat pada perjanjian "bersyarat" merupakan suatu kesatuan yang tidak terpisah dalam perjanjian. Syarat dalam perjanjian "bersyarat" bukan tambahan yang ditempelkan dalam perjanjian, melainkan meliputi atau materi perjanjian. ${ }^{20}$

Dari uraian asas-asas hukum dan kasus yang telah terjadi dalam hal pelaksanan atau eksekusi putusan Badan Arbitrase Syariah Nasional, sebagai landasan konstitusional bagi pelaksanaan Sistem Ekonomi Syariah maupun Arbitrase Syariah di Indonesia Pasal 29 ayat (2) Undang-Undang Dasar 1945. Kewenangan Absolat Pengadilan Agama adalah ditegaskan dalam penjelasan Pasal I angka 37 , mengenai Perubahan bunyi Pasal 49 UU No. 7 1989, pada point (i) disebutkan bahwa ekonomi syariah termasuk di dalamnya arbitrase syariah merupakan kewenangan Pengadilan Agama.

Kewenangan Pengadilan Agama sudah tegas diatur juga dalam perundang-undangan, namun masih saja ada usaha tertentu, yang dengan sadar atau tidak sadar, seperti Pasal ayat (2) Undang-Undang Nomor 21 Tahun 2008 tentang Perbankan Syariah yang menentukan:

${ }^{18}$ Dalam sejarah keagamaan, Istilah ummatan muslimatan (umat muslim), selambatlambatnya untuk pertama kali digunakan oleh nabi Ibrahim alaihis-salam (perhatikan al-Quran surat al-Baqarah (2):128).

${ }^{19}$ M. Yahya Harahap, “Arbitrase”, (Jakarta: Pustaka Kartini, 1991), hal. 22.

20 Suyud Margono, "ADR-Alternative Dispute Resolution dan Arbitrase Proses Pelembagaan dan Aspek Hukum”, (Jakarta: Ghalia Indonesia, 2000), hal. 116. 
1. Penyelesaian sengketa perbankan syariah dilakukan oleh pengadilan agama.

2. Dalam hal para pihak telah memperjanjikan penyelesaian sengketa selain sebagaimana dimaksud ayat (1), penyelesaian sengketa dilakukan sesuai dengan akad.

3. Penyelesaian sengketa sebagaimana dimaksud ayat (2) tidak boleh bertentangan dengan prinsip syariah.

Tegas-tegas memberikan kewenangan mengadili sengketa perbankan syariah kepada Pengadilan Agama, tetapi penjelasan ayat (2) pasal tersebut pada huruf d menentukan, "yang dimaksud pengadilan dalam lingkungan peradilan umum”. Ketentuan tersebut nyata mengebiri kewenangan peradilan agama.

Berhubung dengan itu, Penjelasan Pasal 55 ayat (2) Undang-Undang Nomor 21 Tahun 2008 Perbankan Syariah oleh Mahkamah Konstitusi dalam Putusan Nomor 93/PUU-X/2012 tanggal 29 Agustus 2013 dinyatakan bertentangan dengan Undang-Undang Negara Republik Indonesia Tahun 1945, yakni 28D ayat (1) yang menyatakan: "setiap orang berhak atas pengakuan, jaminan, perlindungan, dan kepastian hukum yang adil serta perlakuan yang sama di hadapan hukum, dan karena itu tidak mempunyai kekuatan hukum mengikat".

Keterbatasan perangkat peraturan perundang-undangan terkait dengan bidang ekonomi syariah termasuk didalamnya Arbitrase Syariah peran Peradilan Agama dalam pelaksanaan atau eksekusi Badan Arbitrase Syariah Nasional harus berpegang teguh pada 13 (tiga belas) prinsip ekonomi Islam sebagai berikut: ${ }^{21}$

1. Ekonomi Islam pengaturannya bersifat ketuhanan/ilahiah (nizhamun rabbaniyyun), mengingat dasar-dasar pengaturannya yang tidak diletakkan oleh manusia, akan tetapi didasarkan pada aturan-aturan yang ditetapkan Allah swt, sebagaimana terdapat dalam al-Quran dan as-Sunnah.

2. Dalam Islam, ekonomi hanya merupakan satu titik bahagian dan alIslam secara keseluruhan (juzun min al-Islam as syamil). Oleh karena ekonomi itu hanya merupakan salah satu bagian atau tepatnya subsistem dan al-Islam yang bersifat komprehensip (al-Islam assyamil), maka ini artinya tidaklah mungkin memisahkan persoalan ekonomi dari rangkaian ajaran Islam secara keseluruhan yang bersifat utuh dan menyeluruh (Holistik). Ekonomi Islam tetap dibangun atas asas-asas akadiah (al-asas al-'aqa'idiyyah) dan asas-asas etika-moral (al-asas akhlaqiyyah).

${ }^{21}$ Muhammad Rawas Qal'ah-ji, "Mahahits fi al-iqtishad al-Islami min Ushulihi alFiqhiyyah”, 1420 H/2000 M (Beirut-Lubnan Dar al-Nafa'is), hal. 54 dikutik dari karangan H. Muhammad Amin Suma, Arah Pengembangan Hukum Ekonomi Islam/Syariah Di Indonesia, "Majalah Hukum Nasional", Nomor 2 Tahun 2007 BPHN, hal. 86. 
3. Ekonomi berdimensi akidah atau keakidahan (iqtishadun 'aqdiyyun), mengingat ekonomi Islam itu pada dasarnya terbit atau lahir (sebagai ekspresi) dari akidah Islamiah (al-'aqidah al-Islamiyyah) yang di dalamnya akan dimintakan pertanggungjawaban terhadap akidah yang diyakininya. Atas dasar ini maka seorang orang muslim (menjadi) terikat dengan sebagian kewajibannya semisal zakat, sedekah dan lainlain walaupun dia sendiri harus kehilangan sebagian kepentingan dunianya karena lebih cenderung untuk mendapatkan pahala dari Allah SWT di hari kiamat kelak.

4. Berkarakter ta'abbudi (thai'un ta a'abbudiyun). Mengingat ekonomi Islam itu merupakan tata aturan yang berdimensikan ketuhanan (nizham rabbani), dan setiapa ketaatan kepada salah satu dan sekian banyak aturan-aturan Nya adalah berarti ketaatan kepada Allah SWT; dan setiap ketaatan kepada Allah itu adalah Ibadah. Dengan demikian maka penerapan aturan-aturan ekonomi Islam (al-iqtishad al-Islami) adalah juga mengandung nilai-nilai Ibadah dalam konteksnya yang sangat luas dan umum.

5. Terkiat erat dengan akhlak (murtabithun bil-akhlaq), Islam tidak pernah memprediksi kemungkinan ada pemisahan antara akhlak dan ekonomi, juga tidak pernah memetakan pembangunan ekonomi dalam lindungan Islam yang tanpa akhlak itulah sebabnya mengapa seperti perdagangan, perkreditan dan lain-lain yang semata-mata murni kegiatan ekonomi sebagaimana terdapat di dalam ekonomi non Islam. Dalam Islam, kegiatan ekonomi sama sekali tidak boleh lepas dari kendali akhlak (etika-moral) yang merupakan sebagian tidak terpisahkan dari ajaran Islam secara keseluruhan.

6. Elatis (al-murunah), dalam pengertian mampu berkembang secara perlahan-lahan atau evolusi. Kekhususan al-murunah ini didasarkan pada kenyataan bahwa baik al-Quran maupun al-Hadits, yang keduanya dijadikan sebagai sumber asasi ekonomi, tidak memberikan doktrin ekonomi secara tekstual akan tetapi hanya memberikan garis-garis besar yang bersifat instruktif guna mengarahkan perekonomian Islam secara global.

7. Objektif (al-maudhu'iyyah), dalam pengertian, Islam mengajarkan umatnya supaya berlaku dan bertindak objektif dalam melakukan aktivitas ekonomi. Aktivitas ekonomi pada hakikatnya adalah merupakan pelaksanaan amanat yang harus dipenuhi oleh setiap pelaku ekonomi tanpa membeda-bedakan jenis kelamin, warna kulit, etnik, agama/kepercayaan dan lain-lain. Bahkan terhadap musuh sekalipun di samping terhadap kawan dekat. Itulah sebabnya mengapa monopoli misalnya dilarang dalam Islam. Termasuk ke dalam hal yang dilarang ialah perlakuan dumping dalam berdagang/berbisnis.

8. Memiliki target sasaran/tujuan yang lebih tinggi (al-hadaf as-sami). Berlainan dengan sistem ekonomi non Islam yang semata-mata hanya untuk mengejar kepuasan materi (al-rafahiyah al-maddiyah), ekonomi 
Islam memiliki sasaran yang lebih jauh yakni merealisasikan kehidupan kerohanian yang lebih tinggi (berkualitas) dan pendidikan kejiwaan.

9. Perekonomian yang stabil/kokoh (iqtishadun bina'un). Kekhususan ini antara lain dapat dilihat dari kenyataan bahwa Islam mengharamkan praktik bisnis yang membahayakan umat insani apakah itu bersifat perorangan maupun kemasyarakatan seperti pengharaman riba, penipuan, perdagangan khamr dan lain-lain.

10. Perekonomian yang berimbang (iqtishad mutawazin), maksudnya ialah bahwa perekonomian yang hendak diwujudkan oleh Islam adalah ekonomi yang berkeseimbangan (berimbang) antara kepentingan individu dan sosial, antara tuntutan kebutuhan duniawi dan pahala akhirat, serta keseimbangan antara fisik dan psikis, kesimbangan antara sikap boros dan hemat (israf daa taqtir).

11. Realistis (al-waqiiyyah). Prakiraan (forcasting) ekonomi khususnya prakiraan bisnis tidak selamanya sesuai antara teori di satu sisi dengan praktik pada sisi yang lain. Dalam hal-hal tertentu, sangat dimungkinkan terjadi pengecualian atau bahkan penyimpangan dari hal-hal yang semestinya. Misalnya, dalam keadaan normal, Islam mengharamkan praktik jual-beli barang-barang yang diharamkan untuk mengonsumsinya, tetapi dalam keadaan darurat (ada kebutuhan sangat mendesak) pelarangan itu bisa jadi diturunkan statusnya menjadi boleh atau sekurang-kurangnya tidak berdosa.

12. Harta kekayaan itu hakekatnya milik Allah SWT. Dalam prinsip ini terkandung maksud bahwa kepemilikan seseorang terhadap harta kekayaan (al-amwal) tidaklah bersifat mutlak. Itulah sebabnya mengapa dalam Islam pendayagunaan harta kekayaan itu tetap harus dikelola dan dimanfaatkan sesuai dengan tuntunan Sang Maha Pemilik yaitu Allah SWT. Atas dalih apapun, seseorang tidak boleh bertindak sewenangwenang dalam mentasarrufkan (membelanjakan) harta kekayaannya, termasuk dengan dalih bahwa harta kekayaan itu milik pribadinya.

13. Memiliki kecakapan dalam mengelola harta kekayaan (tarsyid istikhdam al-mal). Para pemilik harta perlu memiliki kecerdasan/kepiawaian dalam mengelola atau mengatur harta kekayaannya semisal berlaku hemat dalam berbelanja, tidak menyerahkan harta kepada orang yang belum/tidak mengerti tentang pendayagunaannya, dan tidak membelanjakan hartanya ke dalam halhal yang diharamkan agama, serta tidak menggunakannya pada hal-hal yang merugikan orang lain.

Untuk mengatasi kendala kewenangan Pengadilan Agama untuk dapat melaksanakan atau eksekusi putusan Basyarnas,Pengadilan Agama, misalnya saja:

1. Penyiapan sumber daya manusia (SDM) menghadapi kewenangan barunya.

2. Penyiapan anggaran yang besar untuk melaksanakan pendidikan dan latihan ekonomi syariah. 
3. Menyiapkan konsep pendidikan dan latihan ekonomi syariah.

4. Tersedianya calon hakim dari kalangan Sarjana Syariah dan Sarjana Hukum yang siap pakai.

5. Orientasi dengan kalangan pakar ekonomi pada umumnya dan pakar ekonomi syariah pada khususnya.

6. Orientasi dengan para praktisi.

Bahwa secara umum pengadilan agama sudah siap menerima, memeriksa dan memutus perkara sengketa ekonomi syariah yang diajukan oleh para pihak yang bersengketa sesuai dengan perintah Pasal 49 UU No. 3 Tahun 2006 tentang Pengadilan Agama.

Bahwa secara filosofis ekonomi syariah didominasi oleh isttilah-istilah bisnis Islam, seperti murabahah, hudaibiyah, musyawarah, mudarabah, qardh, hawalah, ijarah dan kafalah. Oleh sebab itu, merupakan hal yang benar dan tepat apabila pelaksanaan atau eksekusi putusan Badan Arbitrase Syariah Nasional dijadikan kewenangan Pengadilan Agama yang secara substantif membidangi hal-hal yang terkait dengan ekonomi syariah.

Bahwa Pasal 61 UU No. 301999 menyebutkan "Dalam hal para pihak tidak melaksanakan putusan arbitrase secara sukarela, putusan dilaksanakan berdasarkan perintah Ketua Pengadilan Negeri atas permohonan salah satu pihak yang bersengketa. Dalam hal ini, aturan sudah jelas menyebutkan bahwa pelaksanaan atau eksekusi putusan Badan Arbitrase kewenangan Pengadilan Negeri, akan tetapi Badan Arbitrase Syariah Nasional merupakan badan khusus dilingkungan Majelis Ulama Indonesia oleh sebab itu, maka para pihak yang memilih Badan Arbitrase Syariah Nasional sebagai tempat penyelesaian sengketanya maka sudah menjadi kewajibannya untuk tunduk pada sistem peradilan yang menjadi hukumnya. Badan Arbitrase Syariah Nasional menyelesai perkara-perkara ekonomi syariah maka secara kewenangan absolut merupakan kewenangan Pengadilan Agama.

Bahwa Pasal 1 ayat (3) UUD 1945, Negara Republik Indonesia adalah negara hukum yang di dalamnya ada dua pengertian yaitu supreme of law dan equality before the law. Penafsiran terhadap supreme of law yaitu kepastian hukum. Pasal 61 UU No. 301999 merupakan suatu kepastian hukumnya untuk para pihak yang bersengketa di bidang Arbitrase. Mengenai pengertian equality before the law yaitu sama kedudukan di depan hukum, jadi kedudukan pengadilan negeri dan pengadilan agama sama di depan para pihak sengketa arbitrase, tetapi karena pengadilan agama telah dijustifikasi oleh undangundang bahwa pengadilan agama mempunyai kewenangan absolut terhadap perkara ekonomi syariah sedang sengketa-sengketa di Badan Arbitrase Syariah Nasional semuanya di bidang ekonomi syariah maka tepatlah apabila pelaksanaan atau eksekusi putusan Badan Arbitrase Syariah Nasional di alihkan ke Pengadilan Agama.

Menimbang bahwa putusan Mahkamah Agung dalam kasus antara PT. Atriumastra Sakti melawan PT. Bank Syariah Mandiri, yang mendaftarkan pelaksanaan atau eksekusi putusan Badan Arbitrase Syariah Nasional ke Pengadilan Agama dibatalkan oleh Mahkamah Aguang. Mahkamah Agung berpegang Pasal 61 UU No. 30 1999. Memerhatikan apa yang ditetapkan oleh 
Mahkamah Agung memang secara kepastian hukum memang dapat dibenarkan akan tetapi kalau negara kita menjunjung tinggi kesamaan kedudukan di depan hukum (equality before the law) tidakkan tersebut merupakan perlakuan diskriminatif terhadap Pengadilan Agama.

Putusan pengadilan agama juga seakan-akan dianggap sebagai putusan "pengadilan kelas dua" tidak dapat dieksekusi sebelum mendapat persetujuan dari ketua landraad (ketua pengadilan negeri) setempat yang dikenal dengan sebutan executoire verklaring atau bisa juga dinamakan fiat executie. Bahkan setelah kemerdekaan, yakni ketika diundangkannya UU No. 1 Tahun 1974 tentang Perkawinan yang dilaksanakan dengan PP No. 9 Tahun 1975 tentang Pelaksanaan UU No. 1 Tahun 1974 tentang Perkawinan, putusan perceraian yang dijatuhkan oleh pengadilan agama harus pula, Dikukuhkan oleh pengadilan negeri setempat. Meskipun pada akhirnya dengan diundangkannya Undang-Undang Nomor 7 Tahun 1989 tentang Pengadilan Agama, putusan pengadilan agama tidak lagi perlu di fiat executie, atau dikukuhkan pengadilan negeri. $^{22}$

Kehadiran Badan Arbitrase Syariah Nasional (BASYARNAS) sebelumnya lebih dikenal dengan Badan Arbitrase Muamalat Indonesia (BAMUI) sangatlah diharapkan oleh umat Islam Indonesia, bukan saja karena dilatarbelakangi oleh kesadaran dan kepentingan umat Islam untuk melaksanakan syariah Islam, melainkan juga lebih dari itu adalah kebutuhan riil adanya praktek perdata secara perdamaian selaras dengan perkembangan kehidupan ekonomi dan keuangan di kalangan umat.

Selain itu juga, adanya keselarasan antara keberlakuan hukum yang di pakai oleh Badan Arbitrase Syariah Nasional bahwa emang secara peraturan perundang-undangan mengenai Aribitrse masih memakai UU No. 31 Tahun 1999 yang menyebutkan kewenangan untuk pelaksanaan atau eksekusi putusan badan arbitrase harus ke pengadilan negeri, akan tetapi khusus untuk Putusan Badan Arbitrase Syariah Nasional diharapkan kewenangan tersebut beralih ke Pengadilan Agama sesuai dengan hukum yang di berlakukan oleh Badan Arbitrase Syariah Nasional yaitu Hukum Islam.

\section{Kesimpulan}

Putusan Badan Arbitrase Syariah Nasional untuk menyelesaikan sengketa Ekonomi Syariah masih menjadi perdebatan yang sangat sengit antara kewenangan pengadilan negeri dan pengadilan agama, kewenangan absolut berdasarkan Pasal 49 UU No. 7 Tahun 2006 menyebutkan secara jelas bahwa kewenangan Pengadilan Agama dalam menangani perkara ekonomi syariah.

Agar hukum ekonomi syariah memiliki kepastian hukum dan para hakim pengadilan agama memiliki rujukan standar dalam menyelesaikan kasus-kasus sengketa di dalam bisnis syariah, khususnya dapat sebagai rujukan hakim

\footnotetext{
22 Muhammad Alim, Beberapa Perlakuan Diskriminatif Terhadap Pengadilan Agama, “Majalah Varia Peradilan”, No. 335 Oktober 2013, hal. 39-40.
} 
pengadilan agama dalam pelaksanaan atau eksekusi Badan Arbitrase Syariah Nasional maka sudah sepantasnya Pemerintah dan Dewan Perwakilan Rakyat (DPR) RI membentuk Undang-Undang Arbitrase Syariah.

Pengertian legislasi, adalah pembuatan undang-undang menjadi hukum positif, atau bisa juga dirumuskan dengan "pengundangan hukum normatif menjadi hukum positif". Istilah legislasi dalam bahasa arab disebut dengan taqnin, bentuk masdar dari qanun. Qanun artinya Undang-Undang, sedangkan taqnin artinya pengundangan atau pembuatan Undang-Undang. Memasukan dan menetapkan ketentuan fikih dalam Undang-Undang disebut legislasi (taqnin). Dengan demikian, legislasi Undang-Undang Arbitrase Syariah membutuhkan pekerjaan besar, akan tetapi merupakan suatu ijtihad kreatif yang mudah-mudah mendapatkan pahala dari Allah SWT. Amin. 


\section{Daftar Pustaka}

Ali, Mohammad Daud. Hukum Islam: Pengantar Ilmu Hukum dan Tata Hukum Islam Di Indonesia, Jakarta: PT. Raja Grafindo Persada, 2000.

Alim, Muhammad "Beberapa Perlakuan Diskriminatif Terhadap Pengadilan Agama”, Majalah Varia Peradilan No. 335 Oktober 2013.

Azhari, H.M. Thahir. Islam, Hukum Islam Dan Eksistensi Arbitrase Islam DI Indonesia, Dalam Arbitrase Islam di Indonesia, Badan Arbitrase Muamalat Indonesia (BAMUI), Jakarta: Bank Muamalat Indonesia (BMI), 1994.

Badan Arbitrase Muamalat Indonesia (BAMUI), Sambutan Ketua Mahkamah Agung Republik Indonesia Pada Peresmian Badan Arbitrase Muamalat Indonesia, Jakarta: Badan Arbitrase Muamalat Indonesia (BAMUI), 1994.

Dewi, Gemala et.al. Hukum Perikatan Islam Di Indonesia, Jakarta: Kencana, 2013.

Djamil, Faturrahman. Hukum Perjanjian Syariah, Dalam Mariam Darus Badarulzaman, et.al., Kompilasi Hukum Perdata, Bandung: Citra Aditya Bukti, 2001.

Djauhari, Achmad. Peran Arbitrase Dalam Sistem Ekonomi Syariah, Majalah Hukum Nasional No. 2 Tahun 2007 Badan Pembinaan Hukum Nasional Kemenhukham RI.

Harahap, M. Yahya. Arbitrase, Jakarta: Pustaka Kartini, 1991.

Lubis, Sulaikin. et.al, Hukum Acara Perdata Peradilan Agama Di Indonesia, Jakarta: Badan Penerbit FHUI, 2006.

Mardjono, Hartono. Menegakan Syariat Islam Dalam Konteks Ke Indonesiaan, Bandung: Mizan, 1981.

Margono, Suyud ADR-Alternative Dispute Resolution dan Arbitrase Proses Pelembagaan dan Aspek Hukum, Jakarta: Ghalia Indonesia, 2000.

Qal'ah-ji, Muhammad Rawas. Mahahits fi al-iqtishad al-Islami min Ushulihi al-Fiqhiyyah. 1420 H/2000 M, (Beirut-Lubnan Dar al-Nafa'is).

Sabiq, Sayyid. Fikih Sunnah 11, Bandung: PT. Alma'Arif, 1980.

Sinaga, Syamsudin Manan. Arbitrase Dan Kepailitan Dalam Sistem Ekonomi Syariah, Majalah Hukum Nasional No.12 Tahun 2007 Badan Pembinaan Hukum Nasional Kemenhukham RI.

Sumitro, Warkum. Asas-Asas Perbankan Islam dan Lembaga-Lembaga Terkait (BAMUI \& TAKAFUL) di Indonesia, Jakarta: PT. Raja Grafindo Persada, 1997.

Usman, Rachamadi. Hukum Ekonomi Dalam Dinamika, Jakarta: Djambatan, 2000. 
Suma, H. Muhammad Amin Arah Pengembangan Hukum Ekonomi Islam/Syariah Di Indonesia, Majalah Hukum Nasional Nomor 2 Tahun 2007 Badan Pembinaan Hukum Nasional Kemenhukham RI. 